6

South Africa's Experience with Public Service Media 



\title{
South Africa's Experience with Public Service Media
}

\author{
Nomonde Gongxeka \\ Independent Researcher, South Africa
}

\section{Abstract}

This study explores the advances made by the Department of Communications (DoC) in transitioning South Africa's communications sector from the Public Service Broadcasting (PSB) to a Public Service Media (PSM). The changes are caused by disruption from evolving technologies and evolving political influences. The study documents efforts to secure the public service approach in South Africa, but also clarifies why practical progress has been difficult. It shows that despite its shortfalls PSB remains crucially important for democratic advancement in this region. Efforts for digitization are underway, however, the process is slower than hoped. The author explains the reasons and presents South Africa as an important case for examining the development, and identifies problems in development, for the public service model in the region. The article reflects on the prevailing position of PSM as advocated by the African Union (AU) and Southern African Development Community (SADC). The results indicate promise for the development of public service broadcasting in the region, and especially in South Africa, but also demonstrate persistent problems keyed to the influence of commercial funding, political insecurity, and difficulties in maintaining editorial independence that is crucial for popular trust in PSM as a public enterprise.

Keywords: Digital media and migration, public service broadcasting, South Africa, media policy and regulation, democracy, editorial independence, commercialization.

Nomonde Gongxeka, PO Box 11380, Zwartkops, Centurion, South Africa 0051.

Email: nomonde.gongxeka@gmail.com

Copyright (C) 2016 (Nomonde Gongxeka)

A. Rahman \& G. F. Lowe (Eds.), Public Service Media Initiatives in the Global South

(C) (-) $\ominus$ Licensed under the Creative Commons Attribution-NonCommercial-NoDerivatives 4.0

cC) International License (CC BY-NC-ND 4.0)

Available at http://monographs.lib.sfu.ca

DOI: $10.21810 /$ sfulibrary.1.13 



\title{
South Africa's Experience with Public Service Media
}

\author{
Nomonde Gongxeka \\ Independent Researcher, South Africa \\ History and Background \\ of Broadcasting in South Africa
}

\begin{abstract}
Our broadcasting policy and regulatory framework is still focused on the traditional structures of the 1990s as many of the policies were developed as far back as during our transitional era in 1993. These frameworks now run the risk of inhibiting the evolution of communications and media services. The convergence of technologies presents significant opportunities but also potential threats for traditional broadcasting systems. (Media Statement by Minister Muthambi ${ }^{1}, 12$ November 2014)
\end{abstract}

For decades the apartheid state's communication culture and machinery had been characterized by censorship; the banning of media channels that aligned themselves with the struggle for equality; physical attacks that terrorized progressive media operations; state control of 'public' broadcasting; and misinformation campaigns and propaganda from media sympathetic to apartheid (SA Media Landscape, 2014).

This is the succinct history and evolution of South African media under the apartheid rule of the Nationalist Party (NP), when television and radio were controlled by the state and there was little media diversity. Today, 21 years on, the media scene in South Africa reflects a postdemocracy journey that began in 1994.

The country's new found freedoms led to the democratization of broadcasting, transitioning it from an apartheid State service to a more genuine form of public broadcasting as a serviceoriented endeavor. The government and policy makers have grappled with how to transform South Africa's media to reflect the factual demographics of the country.

The democratization of South African broadcasting became a crucial aspect of the country's liberation. Two decades later, the Constitution guarantees media freedom; there is increasing diversity; there are many community radio stations; there are industry bodies to ensure media accountability; and journalists are able to work without intimidation or fear (SA Media Landscape, 2014, p. 4). But a lot remains to be done and, as this article documents, there are persistent problems that are partly rooted in commercial influences and partly in political meddling.

${ }^{1}$ Muthambi was appointed as Minister of Communications in May 2014 by South Africa's President Jacob Zuma. 
During South Africa's apartheid rule regime, Radio 702 (a commercial radio station) and Bophuthatswana TV (Bop TV2), were the only competitors for the South African Broadcasting Corporation (SABC), which also owned the signal distributor Sentech. The country at the time had only two licensed television operators that offered five channels to an audience of around 14 million. In 2015, South Africa boasts sixteen licensed television operators delivering television services across more than 170 channels to an audience of around 40.1 million people (National Association of Broadcasters (NAB), 2014 Report, p. 5), and there are over 250 licensed radio stations with a combined weekly audience of around 33.2 million listeners. Thus, it's clear that broadcasting has enjoyed tremendous growth in South Africa in the democratization period, and without question broadcast media have been and continue to be an instrumental factor in the process.

Reg Rumney stated that in 1994 there were four big media groups, mostly print based but with some interest in the nascent electronic media. They still exist in $2015^{3}$. But two decades on, the press in South Africa has experienced astonishing decline in newspaper circulation, paralleling conditions in the West, and the transfer of advertising revenue has moved decisively to favor broadcasting. Television is now the leading medium for advertising and audiences enjoy more services and programs in more languages and genres than ever before.

\title{
Institutional Frameworks The DoC, ICASA, and SABC
}

\begin{abstract}
The post 1994 era can be described as the most intense policy process ever undertaken in the country, where South Africa had to repeal about 700 laws in order to create a constitutional state founded on democratic principles. Governing is about law making, which must later translate into practice. Each and every law had to be redefined in a very complex process, and the first step was to repeal the 1976 Broadcasting Act. $\left(\mathrm{Mjwara}^{4}, 2014\right)$
\end{abstract}

The impressive gains that broadcast media have made in the past twenty years are partly owing to legal supports and policies that have encouraged the development of an institutional framework to facilitate development - and most importantly, here, the transition from state broadcasting towards a more genuine form of public service broadcasting at the SABC.

2 Bop TV remained independent until it was absorbed into the SABC in the 1990s.

3 These media groups are namely: Times Media Limited (TML) now renamed Times Media; the Argus Group now renamed Independent Newspapers; Nasionale Pers now renamed Naspers and Perskor was replaced by Caxton-CTP (SA Media Landscape, 2014, p. 40).

${ }^{4}$ Respondent interview with the Advisor to Minister, Department of Communications, South Africa. The author employed qualitative research methodology (semi-structured in-depth interviews) to collect some data for this research. Four respondents were interviewed as a part of her thesis in Master of Management Degree in ICT Policy and Regulation at the University of Witwatersrand. Existing literature was also examined, and subjected to secondary data analysis. 
The period from 1991 to 1993 can be best described as the pre-transition phase in the politics of South Africa, when a foundation was laid for new institutional arrangements in the broadcasting and telecommunications sectors. This reform process led to the formation of the Department of Communications (DoC) for policy making and separate regulatory bodies for oversight - the Independent Broadcasting Authority (IBA), which was responsible for broadcasting, and the South African Telecommunications Regulatory Authority (SATRA), which was responsible for telecommunications. The reform process culminated in the adoption of South Africa's 3-tier broadcasting system (public, community, and commercial), the entirety of which is premised on public service mandate and seeks to enable a diverse broadcasting industry.

The institutional structure has been a crucial factor to facilitate the development of media in South Africa, and more precisely efforts to cultivate a democratic media system in broadcasting. The structure is illustrated in Figure 1.

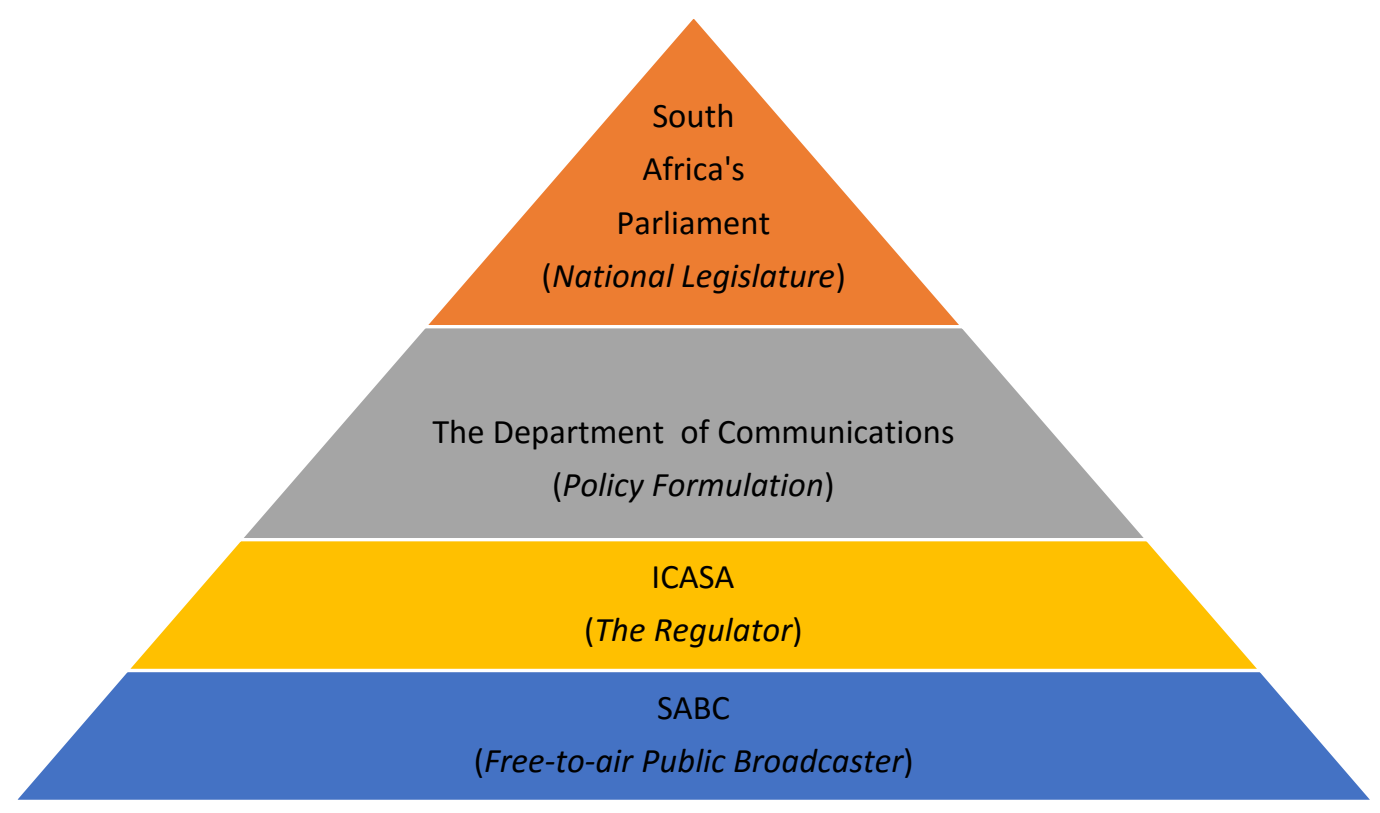

Figure 1. The Doctrine of Separation of Powers (CISHE, 2013).

At the time, whilst determined to liberalize the media landscape, the DoC created the necessary space for convergence and this was enabled by a good policy foundation which created the necessary space to maneuver (Mjwara, 2014).

By 1996, the Constitution of South Africa was in place as the framework for the country's young democracy. By 2000 the convergence of technologies led to changes in the regulatory framework, which saw the amalgamation of the once separate regulatory bodies (IBA and SATRA) merged into a single regulatory body known as the Independent Communications Authority of South Africa (ICASA), as pictured in Figure 1.

However, following South Africa's fifth democratic elections in May 2014, President Jacob Zuma reshuffled the Cabinet. This resulted in the splitting up of the DoC into two separate 
ministries, in essence reverting to the analogue era arrangement. This move baffled the sector and industry practitioners and no explanation was provided for the split by the Presidency. The DoC was divided into the Department of Telecommunications and Postal Services (DTPS) led by Minister Siyabonga Cwele, and a new "reconfigured" DOC overseen by Minister Faith Muthambi. In the run-up to South Africa's democracy, the African National Congress (ANC), crafted the ruling party's "Ready to Govern" policy document, which identified the communications sector as a critical growth sector. Notably, the National Development Plan $(\mathrm{NDP})^{5}$ envisioned that by 2030 a high quality communications infrastructure, services, content and applications would be in place, seeing this as key to rapid economic, social and cultural development for the country ${ }^{6}$.

\section{The South African Broadcasting Corporation (SABC)}

Broadcasters globally are undergoing profound transformation, caused by shifts in the world economy, new technologies, changes in audience behaviors and increasingly complex competitive environments. Within this context, the SABC seeks to reshape its future with a strategic plan that provides a clear sense of direction towards a digitalized infrastructure:

The future of the SABC can no longer be based on radio and television, the public broadcaster needs to be a multimedia organization and utilize the prevailing technologies and platforms that exist in order for it to be relevant, hence the SABC must redefine itself. The risk is that if you do not respond to changes around you as a business you then become irrelevant. (Mjwara, 2014)

The public broadcaster's 'core business' is to deliver a variety of high quality programs and services through television and radio, which inform, educate, entertain, and support the public interests at large. This was enshrined in the Broadcasting Act 4 of 1999, and it reflects the general, historical orientation that classically describes a public service ethos in broadcasting. In her foreword outlined in SABC's 2014 Annual Report, Zandile Tshabalala (Chairman: SABC Board) said that the SABC is aware that rapid and fundamental changes will take place in the media landscape during 2014 to 2017, the most significant of which would be the launch of Digital Terrestrial Television (DTT). This poses significant challenges to the Corporation as a project and for funding (SABC Annual Report, 2014).

5 The National Development Plan is an Economic Policy framework which is "geared towards the improvement of South Africa's economic growth and prospects. It aims to fulfil the objectives of reducing poverty and inequality in South Africa by 2030. The main objectives of the NDP are: job creation, a more equitable distribution of wealth, and improving education." (Gazava, 2013)

6 The NDP specifies that "public services and educational and information products will be accessible to all, and will build on the information, education and entertainment role envisaged for public broadcasting", and says the sector "will continue to reduce spatial exclusion, enabling seamless participation by the majority in the global ICT system, not simply as users but as content developers and application innovators."(Minister of Communications, 2013, p. 13) 


\section{Operationalizing the $\mathrm{SABC}$ and the funding model}

Operating a $24 / 7$ broadcaster has huge operational costs. The SABC had to devise funding strategies to keep its operations afloat, and this is the reason for today's mixed funding model. The general economic conditions for the population as a whole means there would not be much potential for increasing public funding, and thus the heavy reliance on commercial revenue.

Since the 2008 global economic downturn, commercial funding has been in decline - as has been the case in most countries. But in South Africa so far, there are no signs of an upswing in the near future. Continued reliance on commercial funding is proving to be quite challenging for the public broadcaster, especially in light of costs to finance the development of a South African multi-channel digital media environment.

The pursuit of targeted audiences in the fragmented media landscape will force commercial companies to spread their budgets across all available multi-media platforms. As elsewhere, the Internet will thin the funding base. Streaming is already viewed as a serious competitive threat, not only to public broadcasters but for all broadcasters in South Africa. This has not happened yet due to the high costs of communication and lack of broadband availability. Internet access and penetration in South Africa remains low at 34 percent (MyBroadband, 2014). But this will all but certainly change in the near future. Given its reach and popularity, television is so far the pre-eminent advertising platform, with the advertising spend ${ }^{7}$ highest during the evening prime-time slot between $18 \mathrm{~h} 00$ and 21h00 (NAB 2014, p. 11). So the threat of disruption is the cause of great concern among broadcasters of all types.

\section{Broadcast ownership in South Africa}

As noted earlier, at the dawn of 1994 media in South Africa had for decades been controlled by white interests and the National Party government clampdown on the press was relentless in reporting about the apartheid past. Radio and television were in state hands and there was little media diversity. The unfolding post-apartheid legislation and regulations led to the liberalization of the airwaves, which over the past 21 years has seen exponential growth of broadcast platforms leading to new players entering the sector and new licenses being issued. What, then, is the situation today for broadcasting in South Africa? In short, the country has a number of television and radio channels and there are three tiers or types of services: public service (via SABC), community broadcasting, and commercial broadcasting. The details are provided below in Figure 2.

Thus, the overall situation for TV, and for television advertising is rather good, but that is not likely to last. As for the SABC, the need for additional capital to fund digitalization has led the PSB operator into a situation where they are directly competing with the commercial sector for capital as well as audiences. This raises questions about the corporation's priorities and is causing complications both in the public service orientation and in relations with private broadcasting companies. In light of the likely decreases in spending on television advertising

7 The increase in revenue has led to increased profits translating to increased contributions which between 2012 and 2014 saw tax contributions rising from R2.3 billion to R3.3 billion. 
as digitalization causes more fragmentation and raises costs, the prognosis is worrisome. Nonetheless, it is clear that South Africa has made tremendous progress in developing its media system to create a diverse mixture of operators and approaches, all of which have been keenly important to the development of democracy.



Figure 2. Licensed Broadcast Operators in South Africa (source: Gongxeka, 2015).

\section{Transition from PSB to PSM}

When analyzing and reviewing the evolution of policy making in South Africa, we ought to be mindful that the sector was very small, the IBA only had to deal with the SABC and SATRA had to deal with one entity, namely Telkom. At that time the focus was just on democratizing the sector. However, with convergence and digitalization, the landscape has become more complex. This is the history that we must keep in mind as the DoC undertakes its policy review process. (Mjwara, 2014) 
In April 2012, under the leadership of Minister Dina Pule in the DoC at that time, a decision was made to undertake a policy review process. "The ongoing technological changes and innovations that are envisaged in the future coupled with the fact that most of the communication related policies were drawn up in the beginning phase of our democracy, necessitate a review of these frameworks and the development of a new policy" (Minister of Communications, 2013, p. 7). This review sought to analyze what had worked in the past with a view to crafting a way forward in deciding how to take South Africa into the digital future. The DoC's strategic plan states that ICT policy development remains an important output of the department and embarking on an ICT Policy Review ${ }^{8}$ represents a paradigm shift [(The Department of Communications (nd), Strategic Plan: 2013/14 - 2017/18, p. 8)].

South Africa's 2013 proposed National Integrated ICT Policy Review Framing Paper, which is in line with the NDP, says that in the short-term the government should conduct a full policy review that should link policy objectives to specific strategies. The Framing Paper set out the objectives and principles that underpinned the policy environment and laid the overall foundation for the discussion paper. ${ }^{9}$ Figure 3 outlines the processes embarked on when undertaking this policy review, to be tabled in March 2015.

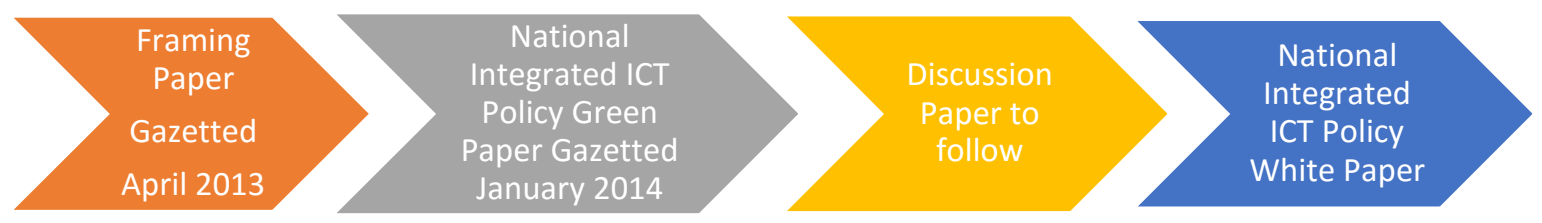

Figure 3. The National Integrated ICT Policy Green Paper Process (source: The National Integrated ICT Policy Gazette 2014)

Minister Pule's tenure was short-lived. She did not stay long enough to see the policy review process through and was replaced in 2013 by Minister Yunus Carim. In 2014 President Zuma made a cabinet reshuffle and Minister Carim was also replaced, by Minister Faith Muthambi who was at the helm at the writing of this article. In the period between 2004 and 2014, the DoC has had six Ministers. This leadership churn has been viewed as an obstacle to South

${ }^{8}$ The long overdue policy review process was seeking to separate the frameworks which had guided the sector since 1994, whose relevancy was under question. It was envisaged at the time that an integrated ICT Policy will assist the DoC to give an unambiguous direction to the sector.

9 The review process was seeking to analyze and review all the existing policies and later culminate in the adoption by government of a new White Paper after its recommendations had been considered by the ICT Policy Review Panel, a panel which was announced in November 2012. The Review Panel comprised of 22 experts and was divided into six focus areas; Broadcasting, Telecommunications and Information Technology, Postal Content Development, Digitizing Government, and Investment and manufacturing (Screenafrica.com, 2012, December 10). The Review Panel's scope of work included but was not limited to making recommendations on the appropriate ICT policy and regulatory framework that sought to support the growth and development of the sector. 
Africa's successful roll-out and implementation of the Broadcasting Digital Migration ${ }^{10}$ (BDM) process. This frequent turnover most certainly contradicts the requirements of long-term policy making (Ngcaba, 2012, p. 4).

It must be noted, however, that since the beginning of the policy review process, and from the articulations which were first made by Minister Pule right through to her predecessors including all the documents reviewed for this study, there has not been any mention of PSM as a concept. When questioned about the DoC's silence on its position regarding the transition from PSB to PSM, Mjwara (2014) said the precise terminology actually does not matter, but that more thinking is required about how the PSB definition will contrast with PSM - and most importantly, how the Ministry can encourage the development and deployment of PSB content and ensure that across the available digital platforms.

Technology does not change our objectives as a Ministry, but it provides us with the means to fulfil our objectives. The question then becomes, does technology change the remit? No, the remit remains the same. What changes is how the remit can be extended to other platforms and the way audiences consume media. As the DoC, we are aware that technology is changing things. We are also aware that when we construct the future it will no longer be about public broadcasting but it will be public media, hence the adoption of a multi-media approach to things. For now as a Ministry, we still call it PSB. Perhaps in the future we may call it PSM. (Mjwara, 2014)

Currie $^{11}$ (2014) recalled there was once some mention of PSM in the now abandoned PSB Draft Bill of 2009, but said that he was not certain when the concept discussion ended. So the question we should perhaps be asking is how the PSM concept can find a way back into the current Green Paper process. "Certainly these are the kinds of things that need to resurface in the current policy review”, added Currie.

South Africa's digital migration process began in 2008 when the DoC published the BDM Policy. It was a priority in the 2009 Draft PSB Bill tabled in Parliament. In 2010, due to internal leadership strife at the DoC the battle ${ }^{12}$ for digital standards ensued. What followed in 2012 was a litigious impasse when e.tv ${ }^{13}$ took Minister Pule to court over the Set Top Box (STB) control pertaining to the inclusion of Conditional Access (CA). This matter was later resolved by the courts in June 2015, ruling in favor of the DoC. South Africa, along with other SADC broadcasters and the rest of the continent, failed to meet the 17 June 2015 Analogue Switch Off (ASO) date.

10 The BDM Policy was approved by Cabinet in 2008 with the pilot test launch having been implemented in November 2008. The policy was aimed at enhancing the lives of citizens through migration from analogue to digital television technology by ensuring national digital coverage and also to bridge the digital divide.

11 Councilor, Independent Communications Authority of South Africa (ICASA). Respondent interview.

12 This was a battle between DVB-T standards and ISDB-T standards, the matter was later resolved when the DoC reverted back to the DVB-T family of standards in line with the Geneva ITU GEO6 Agreement and as was originally agreed upon within Region 1.

${ }^{13}$ Free-to-air commercial broadcaster licensed in 1998. 
But in fact, Mjwara's point is well taken. Succeeding in the transition to a fully digitalized and mature modern media system is certainly important. And yet it is not in itself, that is to say as a technology project per se, the most important thing for South African democracy. The most important thing is the preservation, development and extension of the public service mission, approach and ethos in South African media. Whatever the type of system, or the conditions of that system in technological terms, the focus and orientation is the crucial concern.

\section{Regional Inter-Governmental Organizations}

Because of the evolving technologies and social context, globally strides have been made to transition public broadcasters from PSB to PSM. This transition is partly a move away from traditional linear broadcasting in an effort to create relevance in today's increasingly nonlinear media environment, and partly to take advantage of new possibilities for improved twoway communications and related advances in technology development. As a continent, Africa has been lagging in this regard for all of the usual reasons: lack of capital, illiteracy rates, poor infrastructure, etc. But it would be a mistake to think that Africa is not making progress to ensure that citizens across the continent are not left behind in the technological wave. Progress is typically slow and certainly uneven, but there is political will and growing interest in prioritizing this aspect of development quite generally.

Over the years, countries across the continent have grouped themselves into Regional bodies, namely the Common Market for Eastern and Southern Africa (COMESA), the Economic Community of West African States (ECOWAS) and the Southern African Development Community (SADC). The rationale for these formations was to set objectives and common goals in respective regions and strive to build strong regional ties. To operationalize this, various steering committees were formed to address the differing issues that affect the regions, with ICTs being one important issue.

Outside the regional groupings, an agreement was reached at the Africa Union's (AU) 23rd Ordinary Session, which was held on 30 June 2014 in Malobo, Equatorial Guinea. The AU agreed to adopt a Common African Position (CAP) on digital migration. In this context, and importantly for our interests, the Member States agreed they should work in unison to protect the interests of the PSB remit in Africa. The focus is on PSB rather than PSM, but this makes sense in light of the general situation as earlier observed. The pace of digital migration has been slow across the continent, but three countries have accomplished analogue switch-off: Tanzania, Rwanda and Mauritius. Another 19 countries have launched DTT of some sort, and eleven more have launched pilots as of June 2015 (see, Balancing Act Report, 2015). Thus, there is progress in developing DTT in Africa, and it is encouraging to find support for the public service ethos and approach within the highest body of intergovernmental relations for the continent.

The SADC Ministers Responsible for Communications, ICT and Postal Services held their own summit on $26^{\text {th }}$ June 2015 in Walvis Bay, Namibia. Mr. Remigious Makumbe, the Executive Secretary and Director of Infrastructure and Services, noted that within the SADC Region, three Member States have met the ITU's deadline for digital switch-over: Malawi, Mauritius, 
Namibia. The rationale for this Ministerial gathering ${ }^{14}$ was to take stock of the progress achieved with various strategies as set out in the regional shared vision Digital SADC 2027 policy (A plan aimed at creating a digital SADC Region by the year 2027).

\section{Critical Issues for Public Service Media}

As signaled earlier in our discussion, there are significant challenges to the development of PSB in Africa - and arguably even more challenges in developing PSM. The core challenges include political and commercial influences that undermine editorial independence, selfcensorship and the erosion of journalistic standards and exploitation and instances of corruption.

The new media corporations have an overriding objective, and that is to distribute their products to the largest number of consumers. The profit logic is driving system development in South Africa (and beyond). Competition is already tough and it increasing. The SABC cannot be completely divorced from these contextual realities. But the trends are worrisome for a genuine public service orientation. As Buku (2015) lamented, the media are supposed to be an arena for rational-critical debate, which is a vital need in African societies today, rather than a stage for advertising - which is largely what we see at this point.

For the PSB remit to claim its space and retain its relevance, the SABC should strive to preserve its tradition of critical thinking and be bold to ask pointed questions, which citizens are often afraid to ask. But the 2006 'blacklisting saga' exposed the SABC's lack of independence, or at least commitment to that, when the corporation refused to invite various expert guests as commentators, primarily including those who would have advanced independent critical views of the government and its policies that are clearly in the public interest. This stance laid bare the fact that SABC managers decided to ignore the broadcaster's editorial code and license conditions, as noted by Currie (2014). The prevailing perception these days suggest that the SABC has lost not only its editorial independence, but also increasingly the sense of credibility it once enjoyed.

The SABC now relies heavily on commercial funding, although news and current affairs programming are barred from receiving any form of sponsorship from commercial entities. This is specified by the public broadcaster's license conditions. Contemporary PSM organizations provide news across platforms because news is a vital service to and for democracy. That principle is deeply embedded in PSB heritage and of broadest continuing importance. It is important to observe that public service news is unique in casting an equally critical eye on economic actors, as well as political actors, and due to their non-profit status in so far as public funding and editorial independence are secure (MC-S-PSM, 2008, p. 19).

14 The meeting was aimed at reviewing the status of the digital migration process among member states especially after the ASO date had lapsed. Across the continent there are other broadcasting affiliates who undertook or are planning to undertake a similar exercise, the regions in question are East Africa (East African Communications Organizations - EACO), Nigeria (Broadcasting Organization of Nigeria), and SADC (Southern African Broadcasters Association - SABA) and as a collective their core focus is to get their broadest media affiliates migrated from analogue to digital. (SADC Media Statement, 2015) 
Again, editorial independence seems to have been compromised in the SABC's news room in 2013 when its Chief Operating Officer (COO), Hlaudi Motsoeneng, called for the production of "70 percent Sun Shine News" (Dibetso, 2013). Motsoeneng's declaration was met with fierce resistance and rightly viewed as editorial interference. The SABC management had to be reminded by journalist of the core ethical principles of journalistic practice, i.e. to tell the truth as fully as possible, to act independently, to minimize harm and to be accountable. ${ }^{15}$

There is proof that South Africa's newsrooms more generally suffer declining independence and are seemingly under siege. This was exemplified in an open letter written by Steven Motale titled "I'm sorry, President Zuma", that was published in The Citizen. Motale admitted to being party to 'the sinister agenda' against President Zuma, and apologized for it (IOL News, 13 August 2015). The essence of the article suggests that independence in the newsroom has been compromised for some years, and this has happened at the behest of media owners who most often want to set the agenda for the politics of the day.

Buku (2015) suggested this apology brought to light the reality of concentrated media ownership in South Africa, where a handful of companies rule the industry. "The apology reveals that many, if not all, newsrooms are managed through careful manipulation confirming that we are swimming in the sea of gutter and gossip journalism. There is everything wrong with propaganda, even in the form of oppositional or sunshine journalism" (quoted in the Daily Maverick, 8 August 2015). Weingarten of The Washington Post described the current state of media as a frantic and undignified campaign to economize while at the same time attracting "eyeballs", which is a dangerous situation. South Africa is sadly an illustrative case.

Buku suggested that South Africa's newsrooms are editorially independent in theory, but the profit motive is driving content to a great degree. Reliance on advertising revenue will limit the provision of content that serves public service obligations, concluded Buku. We see, then, that PSB in South Africa is caught on the horns of a dilemma. The majority of South Africans rely solely on the SABC for most of their programming contents, including news programming. When the PSB mandate is undermined by the lack of editorial impartiality, then the public sphere for discussion is thwarted and the premise of promoting and upholding a democratic society is threatened. Also, when the remit is foregone for commercial reasons, then the interests of the public does not get serviced adequately and the PSB obligations are neglected.

\section{Diversity of Content, Censorship, and Extreme Measures}

If you talk to a man in a language he understands, that goes to his head. If you talk to him in his language, that goes to his heart - Nelson Mandela.

${ }^{15}$ These principles are broadly reflected within the SABC's existing editorial policy, SABC Sunshine News Strategy ‘deeply concerning', said policies said Lethabo Dibetso (Mail and Guardian, 30 August 2013 - mg.co.za). 
South Africa is best described as 'the rainbow nation'16, a term made official by Nobel Peace Prize winner Archbishop Desmond Tutu when describing the country's post-apartheid era. South Africa's eleven official languages ${ }^{17}$ are proof of the multiracial and multicultural society, as enshrined in the Constitution.

PSM is crucial for building social capital by ensuring intercultural understanding and crosscultural dialogue (Jauert \& Lowe, 2005). In South Africa, content is broadcast in a multitude of languages covering the country's major language groups, even more successfully in radio than in television. The most watched programs are locally produced in South Africa. Audiences resonate with them and these programs will always find a place with audiences [Bulbulia, 2014, CEO, National Association of Broadcasters (NAB). Respondent interview].

As part of the SABC's strategy in its pursuit to grow and retain audiences, SABC1, SABC2 and SABC3 have tried to revive and revamp their programming pillars. The channels introduced fresh titles in genres such as drama and comedy, informal knowledge building and entertainment programming. The public broadcaster made a cash investment of R937m in TV programming, of which 74 percent (R693m) was for local content - an unparalleled achievement (SABC Annual Report, 2014, p. 22). SABC continues to provide the most watched channels in the country, and audience loyalty has remained strong, particularly with respect to local dramas.

\section{The Importance of the PSM Reform Movement and Advocacy}

Because of the politics of South Africa's apartheid era, the country had a robust civil society to a degree that some might find surprising. This was due to the need to organize resistance, and thus much of what was done happened underground. This cultivated some mastery of organizational skills (Thorne ${ }^{18}, 2014$ ). The robust nature of this accomplishment was evident in 1991 during the Convention for a Democratic South Africa (CODESA) ${ }^{19}$ negotiation process, which garnered widespread public participation. However, since then we have seen a gradual deterioration. Twenty years ago during the analogue terrestrial landscape things were much simpler, of course; the environment was not as technically complex for broadcasting and telecommunications.

Today things are too complex for ordinary activists on the ground to provide meaningful input during participatory stakeholder engagements. The only people with a strong voice today are lawyers and business people who have the deep pockets and technical support to exert influence. This could threaten South African democracy, suggested Thorne (2014), who also lamented the aging of yesterday's activist generation.

${ }^{16}$ South Africa's colorful flag also depicts a rainbow nation, comprising of a diverse population, with different races, cultures, heritage, religion and languages.

17 The official languages are isiZulu, isiXhosa, isiNdebele, Siswati, Sepedi, Sesotho, Setswana, Tshivenda, Xitsonga, English and Afrikaans. Chapter 2 of the Bill of Rights, No 30. states that, everyone has the right to use their own language and to participate in the cultural life of their choice, it is in this spirit that South Africa's media is shaped (The Pan South African Language Board).

18 Association of Community Television and Cape Town Community TV. Respondent interview.

19 It is the Convention for a Democratic South Africa, a negotiation forum that was set up in 1991. 
Perhaps Thorne goes too far, however. There is active advocacy on a smaller but persistent scale, and industry organizations ${ }^{20}$ are striving to engage with the issues affecting the sector. In recent years these organizations have been very active and have held the DoC, ICASA and the SABC to account, sometimes to the extent of staging protests. These advocacy groups play an important role in South Africa's media, ensuring that informed and media literate audiences are empowered to hold media accountable for what they do and fail to do.

\section{Assessment and Recommendations}

Policy practices travel across borders and lessons can be learnt from Europe and other more developed countries in efforts to 'leapfrog' South Africa, the SADC Region and the rest of the continent into a more mature condition. For our interests here, this has particular relevance to the development of PSB (first) and, eventually, PSM because this clearly matters for successful democratization.

To maintain relevance in the era of the always connected yet increasingly fragmented society, this era of the Internet of Things, public broadcasters must reengineer their operations to adapt to this fast paced, technologically charged environment where audiences have the 'tyranny of choice'. In order to attract and retain future audiences, and most specifically today's youth who seem to have less contact with public broadcasters, PSB must devise strategies to reach across generations. Their content must transition from an era of family viewing to an era that is more individualized, and they will have to adapt to the preferences of the digital native youth - where a clash of taste and preferences is characteristic.

But more fundamentally, it is vital that PSB organizations ensure the ethic and advance the mission of public service. The lack of editorial independence in too many news rooms caused by the self-interested meddling of media owners, corrupt practitioners and governments pose an existential threat to the future and significance of PSB in Africa today, and therefore to PSM tomorrow. In fact, it is in the self-interests of public broadcasters to guard against interference and dilution, both, as the best means to safeguard their relevance. This is a core challenge and requirement for today's SABC managers. Failing that, the entire enterprise will become a failure.

Funding for all broadcasters in the wake of Over-the-Top (OTT) operators are also challenged. OTT operators provide an alternative for audiences and consume a growing proportion of the media space without having to commission new content and without having to deal with policy makers and regulatory bodies. Many of them are transnational operators and do not actually care about Africa's societies or their development as anything other than markets, and mainly only in that to the extent that the profits accrue to themselves.

20 Some of these organizations are to name but a few; Save Our SABC (SOS) Coalition - Support Public Broadcasting, Association of Community Television -South Africa (ACT-SA), Media Monitoring Africa (MMP), Independent Producers Organization (IPO), South African, Digital Broadcasters Association (SADIBA), South African Communications Forum (SACF) and Section 27 a public interest law center promoting human rights. 
A multiplatform environment poses challenges, as well, in achieving healthy degrees of social cohesion. This, too, is especially important for the SABC to prioritize. More funds will be required by broadcasters to ensure suitable content across all their channels and devices and to produce local content, which has proven to be the most watched by audiences. PSB has a heritage mission that is still vital for South Africa, and indeed for most of Africa, in supporting the growth of civil society, the health of social relations between diverse peoples, and the collective interests that are essential to a shared quality of life.

African countries are not resisting the digital transition. It is coming and has already arrived in some of these countries. It is also encouraging to find such consensus in principle, at least, about the need for PSB and an emerging understanding that PSM is an extension of PSB tenets and values. Although South Africa, the SADC Region and the rest of the continent are still deeply challenged by development of many kinds, including especially the migration to digital media system, most seem ready to embrace the challenge. This is an opportune moment to discuss, to debate and to advocate development in broadcasting (and online) because, having missed the ASO date of 17 June 2015, many African countries are again focusing on policy reviews and digital migration processes.

Economic development and democratic development go hand in hand here. There is much that Africans can learn from the historic experience of PSB where that has been most successful and remains important, i.e. Europe. There should also be much for everyone to learn from what happens now in Africa. In that regard, South Africa is a particularly important case for achieving potentially enormous advances that could be influential for the region. How the challenges treated in this article are addressed, or not, has implications for South Africa and beyond.

\section{References}

Balancing Act Report. South Africa (June 2015). DTT: Analogue to digital migration in Africa Strategic choices and current developments. Retrieved from http://www.balancingactafrica.com

Berger, G., \& Masala, Z. (2012). Mapping digital Media: South Africa. Open Society Foundations. Retrieved from https://www.opensocietyfoundations.org/sites/default/files/mapping-digitalmedia-south-africa-20120416.pdf

Buku, L. (2015). Citizen editor's apology exposes lie of self-regulation - Opinionista. Retrieved from http://www.dailymaverick.co.za/opinionista/2015-08-18-citizen-editors-apology-exposeslie-of-self-regulation/\#.veqrt mqqko

Bulbulia, N. (2014, January 28). Personal interview.

Currie, W. (2014, February 14). Personal interview.

Dibetso, L. (2013). SABC Sunshine News. Mail and Guardian. Retrieved from http://www.mg.co.za

Gazava, M. (2013, September 23). The National Development Plan: A discussion. news24. Retrieved from http://m.news24.com/news24/MyNews24/The-National-Development-Plan-ADiscussion-20130923 
Jauert, P., \& Lowe, G. F. (2015). Cultural dilemmas in public service broadcasting: RIPE@2005. Göteborg, Sweden: Nordicom.

MC-S-PSM (2008). Report prepared by the Group of Specialists on Public Service Media in the Information Society (MC-S-PSM), November 2008. Retrieved from http://www.coe.int/en/web/freedom-expression

Minister of Communications. South Africa (2013). Proposed ICT Policy Review Framing Paper, 2013. Retrieved from http://pmg-assets.s3-website-eu-west1.amazonaws.com/130426proposedictpolicyreviewframingpaper2013.pdf

Mjwara, J. (2014, March 6). Personal interview.

Motale, S. (2015). “Letter: I am Sorry, President Zuma” - The Citizen, Editor Steven. Retrieved from http://www.iol.co.za/news/letter-i-m-sorry-president-zuma-1.1899205\#.Vd1ow mqqko August 132015

Muthambi Media Statement. South Africa (2014). Minister Faith Muthambi. Retrieved from http://www.doc.gov.za/content/newsroom/media-releases/mediastatements/Minister Muthambi Digital Terrestrial Television12Nov2014

MyBroadband (2014). SA Internet penetration stats. Retrieved from http://www.mybroadband.co.za

National Association of Broadcasters (2014). State of the broadcasting industry report. Retrieved from http://www.nab.org.za/uploads/files/NAB State of the Broadcasting Industry Report 2 014 - November 2014 \%28Final\%29.pdf

Ngcaba, A. (2012, April). Building a digital life for all South Africans - Building an ICT ecosystem through an inclusive consultative process. Paper presented at the Department of Communications National Integrated ICT Policy Colloquium, South Africa.

Rumney, R. (2014). Media landscape 2014: Celebrating 20 years of South Africa's media. Retrieved from

http://www.gcis.gov.za/sites/www.gcis.gov.za/files/docs/resourcecentre/Media\%20Landsca pe\%20book WEB.pdf

SABC Annual Report (2014). SABC Annual Report. Retrieved from http://www.sabc.co.za/wps/portal/SABC/SABCDOCSREPORTS

SADC Media Statement (2015). SADC Media statement on the meeting of SADC Ministers responsible for communications, ICT and postal services - Walvis Bay, Namibia, 26 ${ }^{\text {th }}$ June 2015.

SADC Regional Infrastructure Development Master Plan (2012). Information and Communication Technologies (ICT) Sector Plan, August 2012. Retrieved from http://www.sadc.int/files/9413/5293/3532/Regional Infrastructure Development Master _Plan ICT Sector Plan.pdf

Screenafrica.com (2012, December 10). The ICT policy review panel announced. Retrieved from http://www.screenafrica.com

The Department of Communications (nd). Strategic Plan 2013 - 2018 and Annual Performance Plan for the fiscal year 2013 -2014. South Africa.

The National Integrated ICT Policy Gazette. South Africa (2014). Gazette No. 37261. Retrieved from http://www.doc.gov.za

The Pan South African Language Board. Retrieved from http://www.salanguages.com

Thorne, K. (2014, January 16). Telephone interview. South Africa. 
